\title{
Rate of serious complications of colonoscopy in Quebec
}

\author{
Maida J Sewitch $\mathrm{PhD}^{1,2,3,4}$, Mengzhu Jiang $\mathrm{MS}^{3}$, Lawrence Joseph $\mathrm{PhD}^{3,4}$, \\ Alan N Barkun MD MSc${ }^{1,2,4}$, Alain Bitton MD ${ }^{1,2}$
}

\begin{abstract}
MJ Sewitch, M Jiang, L Joseph, AN Barkun, A Bitton. Rate of serious complications of colonoscopy in Quebec. Can J Gastroenterol 2012;26(9):611-613.
\end{abstract}

BACKGROUND: The rate of serious complications is one marker of the quality of colonoscopy services.

OBJECTIVE: To estimate the rate of serious complications of colonoscopy according to colonoscopy indication and polypectomy status.

METHODS: A prospective cohort study of patients scheduled for colonoscopy who were recruited from seven endoscopy facilities across Montreal (Quebec) was conducted. Before colonoscopy, patients completed a brief questionnaire and provided their health insurance numbers. Colonoscopy indication was based on patient-reported medical history. Polypectomy status was obtained from provincial physician billing records (Régie de l'assurance maladie du Québec). Diagnoses and procedures associated with hospitalization in the 30 days following colonoscopy were obtained from the provincial hospitalization database (MedEcho).

RESULTS: Of the 2134 patients enrolled (mean age 60.9 years, $50.1 \%$ male), 33 (1.55\% [95\% CI 1.06\% to $2.16 \%$ ]) were hospitalized within 30 days. One patient experienced bleeding following a colonoscopy that involved polypectomy and was diagnosed with carcinoma in situ of the rectum. Based on self-reported rectal bleeding in the previous six months, the colonoscopy was nonscreening. The provincial hospitalization data showed no occurrences of perforation, diverticulitis, myocardial infarction/stroke or death; thus, the rate of serious colonoscopy complications was $0.05 \%$ (95\% CI $0.00 \%$ to $0.26 \%$ ).

DISCUSSION: The rate of serious colonoscopy complications requiring hospitalization was low and comparable with what is reported in the literature. The serious complication occurred subsequent to polypectomy and in a nonscreening colonoscopy.

CONCLUSION: The findings support the relative safety of screening colonoscopy in persons without large bowel diseases and symptoms. However, future research to determine the rate of serious complications not requiring hospitalization is warranted to reassure decision makers of the safety of colonoscopy for colorectal cancer screening.

Key Words: Colonoscopy; Complications; Screening

C olonoscopy is the only screening modality for colorectal cancer (CRC) that enables detection and removal of precancerous and cancerous lesions throughout the colon (1-5). However, colonoscopy is not readily available, inexpensive or easy to administer, and results are not reliable or reproducible because endoscopist and practice setting characteristics are associated with postcolonoscopy CRC (6). Importantly, colonoscopy is not completely safe, and serious complications of colonoscopy are no longer uncommon events due to the increased number of colonoscopies performed annually $(7,8)$. In one Canadian study, pooled rates from British Columbia, Alberta,

\section{Les taux de graves complications de coloscopie au Québec}

HISTORIQUE : Le taux de graves complications sont un marqueur de la qualité des services de coloscopie.

OBJECTIF : Évaluer le taux de grave complication de la coloscopie d'après l'indication de coloscopie et le statut de polypectomie.

MÉTHODOLOGIE : Les auteurs ont mené une étude de cohorte prospective auprès des patients devant subir une coloscopie recrutés dans sept installations d'endoscopie de Montréal (au Québec). Avant la coloscopie, les patients ont rempli un bref questionnaire et fourni leur numéro d'assurance maladie. L'indication de coloscopie se fondait sur les antécédents médicaux des patients. Les auteurs ont obtenu le statut de polypectomie dans les dossiers de facturation des médecins de la province (Régie de l'assurance maladie du Québec). Ils ont obtenu les diagnostics et les interventions associés à l'hospitalisation dans les 30 jours suivant la coloscopie dans la base de données d'hospitalisation de la province (MedEcho).

RÉSULTATS : Sur les 2134 patients inscrits (âge moyen de 60,9 ans, $50,1 \%$ de sexe masculin), 33 (1,55\% [95\% IC 1,06\% à 2,16\%]) ont été hospitalisés dans les 30 jours. Un patient a subi une hémorragie après la coloscopie, laquelle incluait une polypectomie, et il a reçu un diagnostic de carcinome in situ du rectum. D'après l'hémorragie rectale autodéclarée dans les six mois précédents, la coloscopie n'avait pas été effectuée pour des besoins de dépistage. Les données d'hospitalisation provinciale n'ont révélé aucune occurrence de perforation, de diverticulite, d'infarctus du myocarde ou d'accident cérébral vasculaire ou de cancer. Ainsi, le taux de graves complications des coloscopies s'élevait à 0,05 \% (95\% IC 0,00 \% à 0,26\%).

EXPOSÉ : Le taux de graves complications de la coloscopie exigeant une hospitalisation était peu élevé et comparable à ce qui est indiqué dans les publications. Ces graves complications se produisaient après une polypectomie et une coloscopie non liée au dépistage.

CONCLUSION : Les observations étayent la sécurité relative de la coloscopie de dépistage chez les personnes asymptomatiques sans grave maladie inflammatoire de l'intestin. Cependant, de futures recherches en vue de déterminer le taux de graves complications n'exigeant pas d'hospitalisation sont justifiées pour rassurer les décideurs quant à la sécurité de la coloscopie en vue du dépistage du cancer colorectal.

Ontario and Nova Scotia for colonoscopy-related bleeding, perforation and death were 1.64 per $1000,0.85$ per 1000 and 1 per 14,000 , respectively (9). Studies of serious complications are heterogeneous and may include flexible sigmoidoscopy and colonoscopy, observation periods that vary from $24 \mathrm{~h}$ to one month $(10,11-14)$, and assessment methods that include electronic records $(12,13,15)$, medical chart review (14) and patient self-report $(10,11)$. Nevertheless, the most frequent complications are postbiopsy and postpolypectomy bleeding, colonic perforation, diverticulitis, myocardial infarction and death (10-12,14).

${ }^{1}$ Department of Medicine, McGill University; ${ }^{2}$ Division of Gastroenterology, McGill University Health Centre; ${ }^{3}$ Division of Clinical Epidemiology,

Research Institute of the McGill University Health Centre; ${ }^{4}$ Department of Epidemiology, Biostatistics and Occupational Health, McGill University,

Montreal, Quebec

Correspondence: Dr Maida J Sewitch, 687 Pine Avenue West, V Building, Room V2.15, Montreal, Quebec H3A 1A1.

Telephone 514-934-1934 ext 44736, fax 514-934-8293, e-mail maida.sewitch@mcgill.ca

Received for publication December 19, 2011. Accepted January 23, 2012 
TABLE 1

Participant characteristics $(n=2134)$

\begin{tabular}{lc}
\hline Characteristic & \\
\hline Age, years, mean \pm SD & $60.9 \pm 7.1$ \\
Male sex & $1070(50.1)$ \\
History of gastrointestinal conditions & $627(29.4)$ \\
Abdominal symptoms in the past 6 months & $853(40.0)$ \\
Anemia in the past 12 months & $227(10.7)$ \\
Positive fecal occult blood test in the past 12 months & $60(2.8)$ \\
Colonoscopy in the past 10 years & $991(46.4)$ \\
Family history of colorectal cancer & $505(23.7)$ \\
Polypectomy performed at index colonoscopy & $548(25.7)$ \\
\hline
\end{tabular}

Data presented as $n$ (\%) unless otherwise indicated

Although the rates of serious complications are very low, the proportion that results from screening colonoscopy is unclear. Thus, the purpose of the present study was to determine the rate of serious complications of colonoscopy requiring hospitalization in the 30 days postcolonoscopy according to colonoscopy indication (screening/nonscreening) and polypectomy status.

\section{METHODS}

Data from two prospective studies, conducted between 2007 and 2009, of individuals 50 to 75 years of age who underwent outpatient colonoscopy and were covered by the provincial health insurance plan (Régie de l'assurance maladie du Québec [RAMQ]) were combined. The first cohort was part of a study to develop algorithms to identify screening colonoscopies in administrative data; the second cohort was assembled to augment the sample size of the first cohort to examine colonoscopy quality and safety issues. The same data collection methods were used in both studies.

Participants were recruited from seven university-affiliated hospitals in Montreal (Quebec); they were approached by the research assistant before colonoscopy and explained the purpose of the study. Individuals who provided written informed consent were interviewed on demographics and gastrointestinal conditions and symptoms. Colonoscopy indication was derived from patient questionnaires. Nonscreening was defined as having any of the following: history of gastrointestinal disease, lower abdominal symptoms in the previous six months, anemia or positive fecal occult blood test in the past year. Screening was defined as the absence of these criteria. Polypectomy status was obtained from RAMQ using the polypectomy billing code, which has been shown to be adequately accurate (16). Hospitalization data on study subjects were obtained from MedEcho (Maintenance et exploitation des données pour l'étude de la clientèle hospitalière), the Quebec health administrative hospitalization database, and individuals who were hospitalized for any reason in the 30 days postcolonoscopy were identified. The lag time (in days) between the index colonoscopy and first hospitalization, as well as the total length of hospital stay, were estimated. The main outcome, serious complications requiring hospitalization, was defined as an event of bleeding, perforation, diverticulitis, myocardial infarction, stroke or death $(10-12,14)$ that occurred up to 30 days postcolonoscopy and identified using diagnostic International Classification of Diseases, Tenth Revison and Canadian Classification of Health Interventions procedure codes that were associated with each colonoscopy complication; these were defined a priori based on expert opinion and discussion with RAMQ technicians.

\section{RESULTS}

In total, 2134 patients (mean age 60.9 years, $50.1 \%$ male) underwent colonoscopy: 689 from cohort 1 and 1445 from cohort 2. Of all the patients, 548 (25.7\%) had one or more polyps removed (Table 1). Of all participants, 33 (1.55\% [95\% CI 1.06\% to 2.16\%]) were hospitalized for any reason at least once during the 30-day time window; two patients $(0.09 \%)$ had two hospitalizations. The median total length of stay for each patient was three days, (range one to 22 days ) and the median time lag time between the index colonoscopy and first hospitalization was 13 days (range 0 to 30 days). Of the hospitalized patients, $\operatorname{six}(17.14 \%$ [95\% CI $6.56 \%$ to $33.65 \%])$ were diagnosed with CRC. Of the serious complications examined, one individual experienced bleeding as a result of a medical procedure; no records were found for perforation, diverticulitis, myocardial infarction, stroke or death (rates $0 \%$ [ $95 \%$ CI $0.00 \%$ to $0.17 \%]$ ). This one participant was $>65$ years of age, had a family history of CRC and self-reported rectal bleeding before colonoscopy, indicating that the colonoscopy was not for screening purposes. Polypectomy had been performed at the index colonoscopy and the participant was hospitalized for one day three weeks postcolonoscopy. The diagnoses associated with this hospitalization were carcinoma in situ of the rectum, bleeding during a medical procedure and misadventures during endoscopic examination. Thus, the rate of serious complications was $0.05 \%$ (95\% CI $0.00 \%$ to $0.26 \%$ ) for all colonsocopies and $0.18 \%$ (95\% CI $0.00 \%$ to $1.01 \%$ ) for colonoscopies with at least one polypectomy. A total of 860 and 1274 colonoscopies were classified as screening and nonscreening, respectively. The rates of serious complications according to indication were $0 \%$ (95\% CI $0.00 \%$ to $0.43 \%$ ) for screening and $0.08 \%$ (95\% CI $0.00 \%$ to $0.44 \%$ ) for nonscreening.

\section{DISCUSSION}

In a cohort of 2134 patients undergoing colonoscopy in Montreal between 2007 and 2009, the rate of serious complications of colonoscopy was $0.05 \%$. This rate is comparable with that reported in a Canadian study of persons 50 to 75 years of age who underwent outpatient colonoscopy between 2002 and 2003 (9). The single complication in the present study occurred following polypectomy, which is a known risk factor for serious complications (12) because serious complications occurred in 7.0 per 1000 colonoscopies with biopsy/ polypectomy compared with 0.8 per 1000 colonoscopies without. This one bleeding episode occurred three weeks postpolypectomy and may have been due more to the follow-up treatment than to the index colonoscopy. This individual reported rectal bleeding in the six months before the index colonoscopy, indicating that it was a nonscreening colonoscopy. Screening colonoscopies in asymptomatic patients tend to have low complications rates. In one study of asymptomatic individuals 50 to 75 years of age without colonic examination in the previous 10 years (11), no perforations or deaths were attributed to colonoscopy; however, major morbidity occurred in nine of $3196(0.3 \%)$. Our findings suggest that complication rates are lower in screening compared with nonscreening colonoscopies.

Study strengths and limitations warrant discussion. The main strength was the prospective study design, which permitted assessment of patient CRC risk factors, colonoscopy indication and polypectomy status before serious complications, reducing the potential for information bias. The main limitations were small sample size and the lack of power to detect serious complications (especially death), and the use of administrative data, the accuracy of which has not been assessed. The rate of serious complications may have been underestimated because diagnostic codes in administrative data tend to have imperfect sensitivity (17). Furthermore, serious complications not requiring hospitalization, such as bleeding that is treated in the emergency room, were not captured.

\section{CONCLUSION}

The rate of serious colonoscopy complications requiring hospitalization in our patient sample was very small, associated with polypectomy and not associated with CRC screening. Our findings support those of others showing the relative safety of screening colonoscopy in persons without large bowel diseases and symptoms. Future research aimed at determining the rate of serious complications not requiring hospitalization is recommended to reassure decision makers of the safety of colonoscopy for CRC screening. 
DISCLOSURE: The authors have no financial disclosures or conflicts of interest to declare.

FUNDING: This research was supported by operating grants from the Canadian Cancer Society and the Fonds de recherche du Québec Santé (FRQS). Maida J Sewitch PhD is a Checheur Boursier Junior 2 of the FRQS.

\section{REFERENCES}

1. Imperiale TF, Wagner DR, Lin CY, Larkin GN, Rogge JD, Ransohoff DF. Risk of advanced proximal neoplasms in asymptomatic adults according to the distal colorectal findings. N Engl J Med 2000;343:169-74.

2. Ross TM, Ross N. How do I screen for colorectal cancer? Can J Diagnos 2003:70-5.

3. Winawer SJ, Stewart ET, Zauber AG, et al. A comparison of colonoscopy and double-contrast barium enema for surveillance after polypectomy. National Polyp Study Work Group. N Engl J Med 2000;342:1766-72.

4. Lieberman DA, Weiss DG, Bond JH, Ahnen DJ, Garewal H, Chejfec G. Use of colonoscopy to screen asymptomatic adults for colorectal cancer. Veterans Affairs Cooperative Study Group 380. N Engl J Med 2000;343:162-8.

5. Feldman GE, McCord CW, Bassett MT, Frieden TR. Screening for colorectal cancer. JAMA 2003;290:191.

6. Rabeneck L, Paszat LF, Saskin R. Endoscopist specialty is associated with incident colorectal cancer after a negative colonoscopy. Clin Gastroenterol Hepatol 2010;8:275-9.
7. Hilsden RJ. Patterns of use of flexible sigmoidoscopy, colonoscopy and gastroscopy: A population-based study in a Canadian province. Can J Gastroenterol 2004;18:2113-9.

8. Vinden C, Schultz S, Rabeneck L. ICES Research Atlas: Use of Large Bowel Procedures in Ontario. Toronto, ON: Institute for Clinical Evaluative Sciences (ICES), 2004.

9. Rabeneck L, Paszat LF, Hilsden RJ, et al. Bleeding and perforation after outpatient colonoscopy and their risk factors in usual clinical practice. Gastroenterology 2008;135:1899-906.

10. Dobrowolski S, Dobosz M, Babicki A, Giowacki J, Nalecz A. Blood supply of colorectal polyps correlates with risk of bleeding after colonoscopic polypectomy. Gastrointest Endosc 2006;63:1004-9.

11. Nelson DB, McQuaid KR, Bond JH, Lieberman DA, Weiss DG, Johnston TK. Procedural success and complicatoins of large-scale screening colonoscopy. Gastrointest Endosc 2002;55:307-14.

12. Levin TR, Zhao W, Conell C, et al. Complications of colonoscopy in an integrated health care delivery system. Ann Intern Med 2006;145:880-6.

13. Levin TR, Conell C, Shapiro JA, Chazan SG, Nadel MR, Selby JV. Complications of screening flexible sigmoidoscopy. Gastroenterology 2002;123:1786-92.

14. Iqbal CW, Chun YS, Farley DR. Colonoscopic perforations: A retrospective review. J Gastrointest Surg 2005;9:1229-36.

15. Bressler B, Paszat LF, Chen Z, Rothwell DM, Vinden C. Rates of new or missed colorectal cancers after colonoscopy and their risk factors: A population-based analysis. Gastroenterology 2007;132:96-102.

16. Wyse JM, Joseph L, Barkun AN, Sewitch MJ. Accuracy of administrative claims data for polypectomy. CMAJ 2011;183:E743-7.

17. Wilchesky M, Tamblyn RM, Huang A. Validation of diagnostic codes within medical services claims. J Clin Epidemiol 2004;57:131-41. 


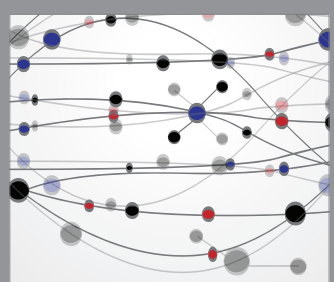

The Scientific World Journal
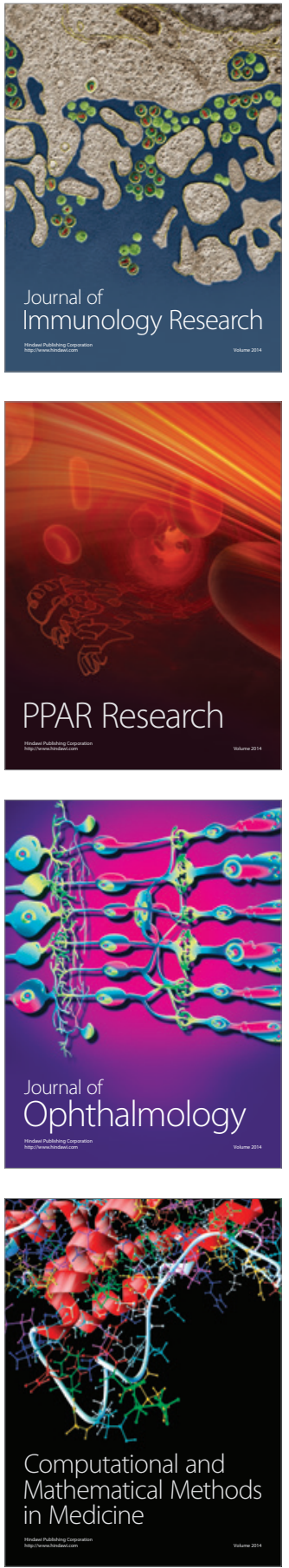

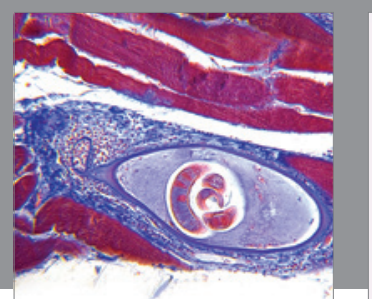

Gastroenterology Research and Practice

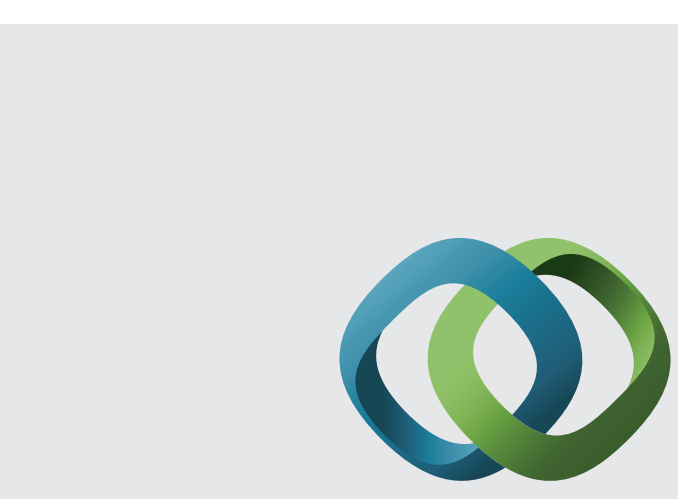

\section{Hindawi}

Submit your manuscripts at

http://www.hindawi.com
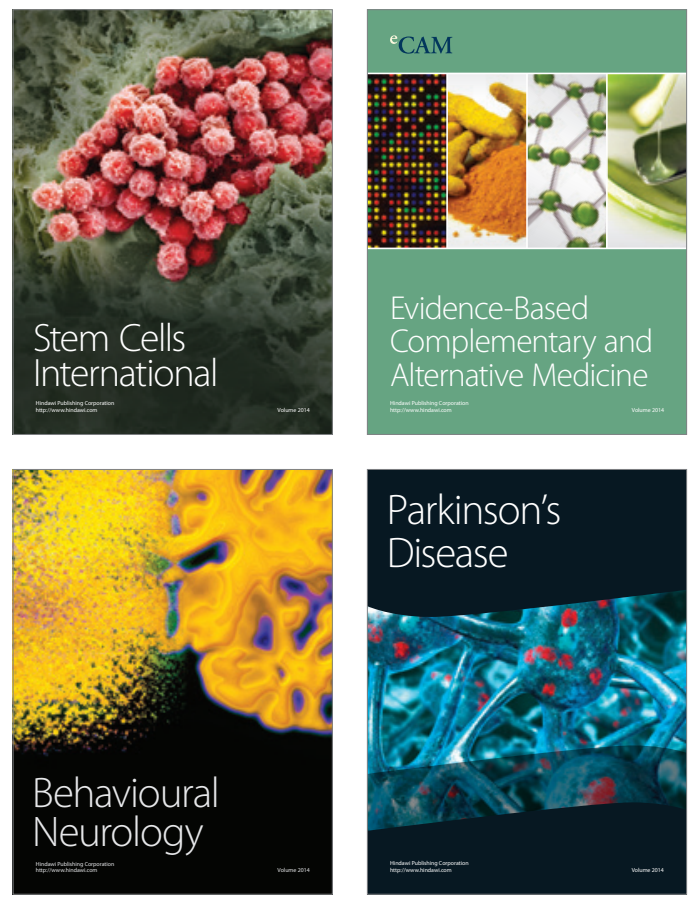
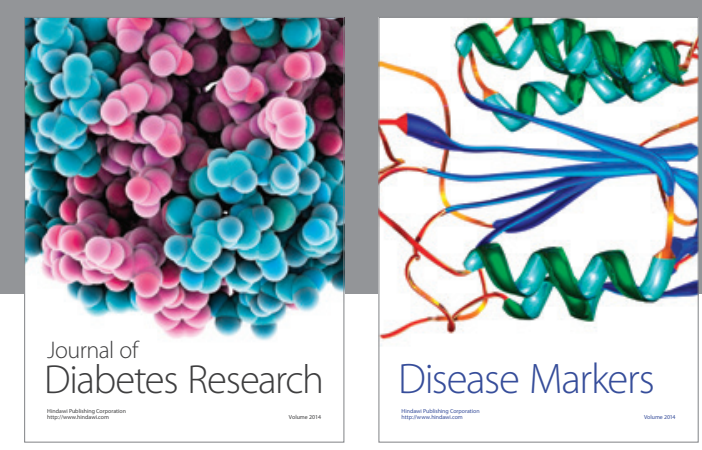

Disease Markers
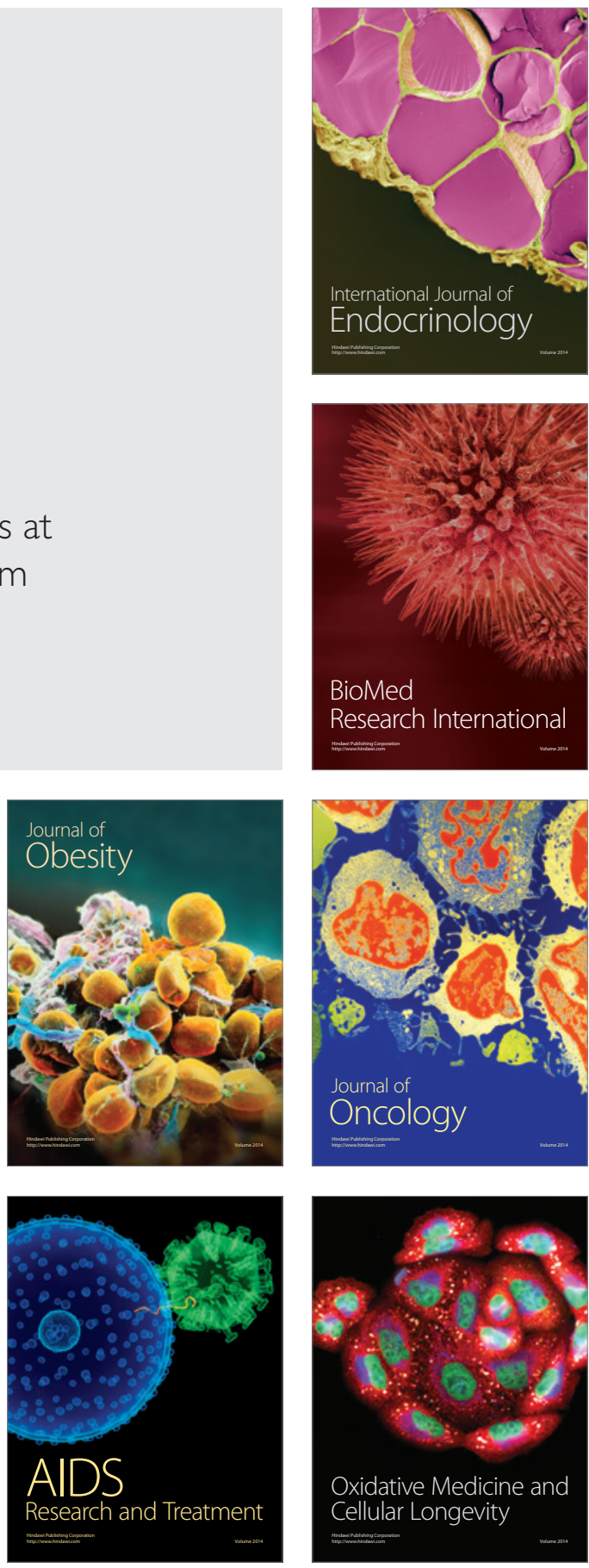